\title{
Una Virgen entronizada con Niño, gótica, de posible origen leonés, en el Instituto Gómez Moreno, de Granada
}

\author{
Ángela FRANCO \\ Museo Arqueológico Nacional. Madrid
}

RESUMEN. Una Virgen entronizada con el Niño, conservada en el Instituto Gómez-Moreno, de Granada, constituye el objeto de este artículo, en el cual se analizan diversos aspectos vinculados a consideraciones teológicas, litúrgicas y estilísticas. Aquí se propone su procedencia leonesa en base a referencias tipológicos, que la vinculan a un origen navarro-riojano, cuyo estilo es transferido a León a través de algunos conventos dependientes del de Tulebras (Navarra).

Palabras clave: entronizada, teología, liturgia, Theotókos (Madre de Dios), concilio ecuménico, Trivium, Quadrivium, Alpha, Omega, iconografía, esfera, libro.

ABSTRACT. The subject of this article is an image of the enthroned Virgin with the Child, preserved in the Gómez Moreno Institute in Granada. This article analyses those aspects which are linked to theological, liturgical and stylistic considerations, whilst also proposing a Leonese origin for the piece. The latter is based on formal references such as the typology, which suggests an origin in the area comprising Navarra and La Rioja. The type and style reached Leon through some convents which depended on that of Tulebras in Navarra.

Key words: enthroned; theology, liturgy, Theotókos (God's Mather), ecumenical council, Trivium, Quadrivium, Alpha, Omega, sphere, book.

Analizar una imagen sagrada aislada de su contexto resulta en general bastante difícil, circunstancia que acompaña a la escultura gótica de la Virgen entronizada con el Niño en brazos, del Instituto Gómez Moreno, de Granada. La dificultad en este caso se acrecienta por la escasez de noticias, como la relativa a su procedencia. La ficha técnica del Instituto proporciona algunos datos referentes a la cronología, tipología, dimensiones. En cuanto a la forma de adquisición, figura dentro de un lote de piezas de la colección Gómez-Moreno donadas a la Institución en 1990, pero no la fecha de adquisición, ni circunstancias de la misma, ni cualquier otro dato que contribuya a desvelar las incógnitas que la acompañan. Fue restaurada por Barbara Hasbach el año de la donación, información que me ha sido proporcionada por Carmen López Pertíñez, a quien agradezco la generosa ayuda prestada. Cuando investigaba sobre el presente artículo, se exhibía en la catedral de La Almudena, de Madrid, la exposición titulada la Inmaculada, en cuyo catálogo se tratan 
temas aquí analizados ${ }^{1}$.

Dicho lo cual, he recurrido al método comparativo para proponer un posible origen, que trataré de desentrañar a lo largo de este estudio. En segundo lugar, la tipología responde a una consagrada en el arte gótico, pero con raíces en el estilo románico, aspecto a tener en cuenta, porque perviven una serie de elementos, que la vinculan a los conceptos teológicos inamovibles a lo largo de la Edad Media, aunque el estilo haya evolucionado. Desde mis primeros años de investigación a propósito de la escultura gótica en León, me he familiarizado con la escultura monumental, que tiene bastantes conexiones con la imaginería, aunque generalmente es considerada hermana menor ${ }^{2}$. Como conservadora de museos tengo acceso directo a las obras, punto muy importante para descubrir aspectos que no desvelan estudios más veloces.

La investigación sobre la imaginería mariana gótica ha proporcionado hermosas páginas a la comunidad científica y ha abierto nuevos caminos de exploración. El pionero de ella en España ha sido D. Manuel Gómez Moreno, quien ha catalogado multitud de imágenes en las provincias de Zamora $^{3}$, León ${ }^{4}$, Salamanca $^{5}$ y Ávila ${ }^{6}$, cuyos

1 Á. Franco Mata, "Santa María de Toledo", Inmaculada. Catedral de la Almudena, Madrid, mayooctubre 2005, Conferencia Episcopal Española, catálogo, pp. 64-66, donde se evidencian concomitancias con la pieza en análisis.

2 Á. FRANCO MATA, Escultura gótica en León y provincia, tesis doctoral dirigida por el prof. D. J. M $\mathrm{M}^{\mathrm{a}} \mathrm{DE}$ AZCÁRATE, publicada parcialmente con el título Escultura gótica en León, León, Diputación Provincial, 1978. Una nueva edición corregida y aumentada y con el título parcialmente variado Escultura gótica en León y provincia (1230-1530), León, 1998.

${ }^{3}$ M. GÓMez Moreno, Catálogo Monumental de España. Provincia de Zamora (1903-1905), Madrid, 1927. Vid. también La Virgen María en la iconografía de la diócesis de Zamora, catálogo exposición, Zamora, 1989, catálogos monumentales, son eso, monumentos al saber y punto de referencia obligada a quienes nos hemos adentrado en el estudio de la escultura gótica. Julia Ara ha establecido para Valladolid cinco tipos de Vírgenes entronizadas, que en línea de máxima convienen a los del resto de la geografía peninsular ${ }^{7}$, aunque como advertiré, algunos elementos tipológicos confluyen en obras de distinto grupo.

Máximo Gómez Rascón ha titulado Theotókos a un catálogo de las imágenes de la Virgen de la diócesis de León, donde ha tratado varios aspectos de la temática mariana $^{8}$. Si bien se han analizado los elementos definitorios de las Vírgenes de transición del románico al gótico, recientemente se ha abordado este asunto de forma algo más precisa por Pedro Paniagua en un estudio titulado "La evolución y sus formas", el cual, aunque referido a la iconografía mariana de la diócesis de Astorga, es extrapolable al resto de los territorios hispánicos y algunos de sus conceptos abordaré aquí. Otras provincias han visto enriquecido el elenco de imágenes marianas, como la riquísima provincia de Navarra, gracias al

donde no se limita a la Edad Media, sino que incluye un amplio abanico de estilos.

${ }^{4}$ M. Gómez Moreno, Catálogo Monumental de España. Provincia de León (1906-1908), Madrid, 1925.

5 M. Gómez Moreno, Catálogo Monumental de Salamanca, Valencia, 1967.

${ }^{6}$ M. Gómez Moreno, Catálogo Monumental de España. Provincia de Ávila, Madrid/Ávila, 1983. Más recientemente Franco Mata, Escultura gótica en Ávila, Ávila, Las Edades del Hombre, 2004.

${ }^{7}$ C. J. ARA GIL, Escultura gótica en Valladolid y su provincia, Valladolid, 1977, pp. 128-146. Vid. también V.V. A.A., Fons del Museu Frederic Marès/1. Catàleg d'escultura i pintura medievals (dir. J. YARZA LUACES Y F. ESPAÑOL), Barcelona, 1991.

8 M. GÓMEZ RASCÓN, Theotókos, León, 1996.

9 P. PANIAGUA FÉLIX, "La evolución y sus formas", Salve Regina. Iconografía mariana en Astorga, Astorga, 2004, pp. 31-48; Id., Arte gótico en Asturias. Imaginería, Orfebrería, Artes Decorativas y Artes del color, tesis doctoral presentada en la Universidad de Oviedo el 20 de junio de 2007, de cuyo tribunal formé parte (inédita). 
estudio monográfico de C. FernándezLadreda Imaginería medieval mariana en $\mathrm{Na}$ varra, donde cataloga imágenes, románicas $y$ góticas ${ }^{10}$. En otras se está trabajando actualmente, como Palencia por parte de mi buen amigo Pedro Luis Huerta.

Aunque varias de las imágenes son de completo bulto redondo, la mayoría se ha tallado para ser adosadas a muros, presentando la superficie posterior plana; incluso en ocasiones ha sido ahuecada la espalda para reducir el peso. Es el caso, por ejemplo, de la Virgen del Instituto Gómez Moreno. El grupo de la Theotókos (Madre de Dios) debe su origen a la necesidad de afirmar la naturaleza humana del Dios encarnado, confiriendo al programa iconográfico cristiano una figura maternal. El I concilio ecuménico de Nicea (325) proclamó y defendió la divinidad de Cristo ${ }^{11}$, pero sólo un siglo más tarde, en el concilio de Éfeso, se declara el dogma de la Theotókos o Mater $D e i$, en contra de las teorías de Nestorio ${ }^{12}$. San Cirilo de Alejandría se opone a las formulaciones de Nestorio con el argumento expresado así: "Esto es lo que en todas las partes del mundo prescribe la doctrina de la estricta ortodoxia, y lo que enseñaron los Santos Padres, que se atrevieron a llamar a la Virgen Madre de Dios Theotókos"13. Las conclusiones del concilio serán aceptadas por los concilios posteriores manteniéndose

10 C. FERNÁNDEZ-LADREDA, Imaginería medieval mariana en Navarra, Pamplona, 1988; Salve. 700 años de arte y tradición mariana en Navarra, catálogo exposición, Pamplona, 1994.

11 L. Perrone, "El concilio de Nicea (325)”, en G. Alberigo, (ed.), Historia de los concilios ecuménicos, Salamanca, 1993, pp. 27-44, sobre todo pp. 32-36; Kelly, J. N. D., Primitivos Credos cristianos (1972), Salamanca, 1980, pp. 247-313.

${ }^{12}$ L. PERrone, “De Éfeso (431) a Calcedonia (451). La cuestión cristológica y la ruptura de la ecumene", G. Alberigo, Historia de los concilios ecuménicos, cit. pp. 67-95.

13 Patrología Griega, 33, 146-147, cfr. M. GÓMEZ RASCÓN, Theotokos, cit. p. 21. vigentes a lo largo de la Edad Media. El II concilio de Nicea (786-787) sentó las bases para la expresión plástica del tema, cuyas raíces arrancan de la época de las catacumbas. Aunque muy accidentado y con conclusiones contradictorias, un siglo más tarde, Teodora, la madre del emperador Miguel (842-867), hizo restaurar las imágenes y favoreció la elección de Metodio, un iconófilo, como patriarca. El sínodo reunido por éste en Constantinopla el 11 de marzo de 843 eliminó definitivamente la iconocla$\mathrm{sia}^{14}$.

Las tesis conciliares tienen su referencia literaria y doctrinal en diferentes escritores medievales, figurando ya en el temprano siglo VII San Ildefonso de Toledo, seguido de diversos teólogos carolingios. Pero será la devoción mariana de los siglos XII y XIII la que dé el espaldarazo al fervor hacia María. San Bernardo de Claraval o Clairvaux (+ 1153) es uno de los cantores más conspicuos. Escritores hispanos, como Fray Juan Gil de Zamora, autor del Liber Mariae, que sirvieron de inspiración a las Cantigas, el rey Alfonso X con sus Cantigas, Raimundo Lulio, con su Llibre d'Ave Mariae, y Gonzalo de Berceo con los Milagros y Loores de Nuestra Señora, recopilan candorosos miracula a ella atribuidos. Además de los Evangelios Apócrifos, sobre todo los dedicados al ciclo de la Infancia ${ }^{15}$, la Leyenda Dorada, escrita por Jacques de Vorágine hacia 1264, es otro puntal en la propagación de las devociones y sobre todo su implicación en la liturgia. No en vano la célebre obra del obispo de Génova, está proyectada como el año litúrgico, que comienza con el Adviento y finaliza con la

\footnotetext{
14 L. PERRONE, "El segundo concilio de Nicea (786787) o séptimo concilio ecuménico", G. ALBERIGO, Historia de los concilios ecuménicos, cit. pp. 127-132.

${ }^{15}$ Los Evangelios Apócrifos. Colección de textos griegos y latinos, versión crítica, estudios introductorios y comentarios por A. DE LOS SANTOS (1956), Madrid, 2003.
} 
Dedicación de la Iglesia ${ }^{16}$. Constaba en origen de 182 capítulos, entre los que dedica a la Virgen, siguiendo el orden del año litúrgico, la Natividad, la Circuncisión, la Epifanía, la Purificación, la Anunciación, la Asunción, la Natividad de la Virgen, la Concepción, la Visitación y la Piedad. A la Asunción dedica un largo y poético capítulo, de gran incidencia en la iconografía ${ }^{17}$.

El arte gótico nació y se difundió en una época en que la devoción de la Virgen estaba en plena expansión. Los grandes fundadores de órdenes religiosas del siglo XII, como San Norberto, y sobre todo el ya citado San Bernardo de Clairvaux, son quienes han contribuido a ampliar el culto mariano, que fue continuado en el siglo XIII por los dominicos. Los temas relativos a la Virgen ocupan una gran extensión en los tímpanos de las iglesias góticas, desplazando en ocasiones al propio Juicio Final, o eventualmente, presidiendo la Virgen la portada de este tema, como en la catedral de León. En la catedral de Chartres había una razón particular para conferir a la Madre de Dios un lugar de honor en el Portail Royal, ya que Notre-Dame era el centro de peregrinación mariana más importante de Francia. En el tímpano de la derecha la Virgen en majestad está flanqueada por dos ángeles, exactamente igual que el tipo bizantino de la Nikopoia: aparece de frente y el Niño está sentado sobre sus rodillas. Otros motivos no vienen de Oriente, como la Virgen coronada; está representada como reina del cielo. En las arquivoltas que rodean el tímpano, se disponen personificaciones de las artes liberales, el Trivium o artes literarias, y el Quadrivium o las artes científicas, que significaban el dominio del saber a lo largo de la edad media. Marciano

-

${ }^{16}$ J. VORÁGINE, La Leyenda Dorada (1982), título original Legendi di Sancti Vulgari Storiado, revisado por el Dr. Graesse, Madrid, 2ª ed. 1984, 2 vols.

17 J. VORÁGINE, La Leyenda Dorada, cit. I, pp. 477498.
Capella escribe su gran obra, con la apariencia de una novela, Sobre las bodas de la Filología y Mercurio [De nuptiis Philologiae et Mercurii]. Un joven casado recibe como regalo de boda las siete artes liberales: grammatica, rhetorica, dialectica, geometrica, aritmetica, astronomia, musica ${ }^{18}$. Las tres primeras componen la Virgen, trono de la sabiduría divina, que se encuentra en el centro de las disciplinas propedéuticas, los instrumentos que permiten comprender la revelación del Nuevo Testamento ${ }^{19}$. La Virgen es el receptáculo de todas las virtudes; es la Virgo prudentissima, de ahí que se le asocien las Virtudes, personificadas en las vírgenes prudentes en contrapartida con los vicios, por las vírgenes necias.

Émile Mâle, el gran iconólogo francés, sistematizador de los grandes programas iconográficos a partir sobre todo de los Specula de Vicente de Beauvais, ha propuesto que la idea de glorificar a la Virgen en el arte es una creación del gran artífice de la abadía de Saint-Denis, el abad Suger ${ }^{20}$. Tema tan importante en el ámbito artístico ha generado abundante bibliografía. Marie Louise Thérel ha acometido en profundidad un análisis monográfico en su espléndido libro le Triomphe de la Vierge-Église, creo que poco conocido en nuestro país, donde echa por tierra la tesis de la primacía de Senlis en el tema iconográfico de la Coronación de la Virgen, de hacia 1170. En efecto, treinta años antes, tres monumentos, Sainte-Marie de la Charité sur Loire, Santa Maria in Trastevere, en Roma y la iglesia de

18 J. PAUL, Historia intelectual del Occidente medieval (1998), Madrid, 2003, menciona las Artes Liberales a lo largo del libro.

${ }^{19}$ W. SAUERLÄNDER, La Sculpture gothique en France. 1140-127 (1970), París, 1972, p. 29.

${ }^{20}$ É. MÂLE, L'Art religieux du XIIe siècle en France (1953), 6 6⿳亠丷厂 ed., París, 1966, pp. 435-437; Id., L'Art religieux du XIIle siècle en France (1898), 8ae ed., París, 1948, p. 256; Id. Art et Artistes du Moyen Age, París, 1927, pp. 209-225. 
Quenington, Inglaterra, ofrecen a la vista de los fieles la imagen de la Virgen triunfante acogida por su Hijo en la gloria celeste ${ }^{21}$. A partir de sus argumentos he ampliado dicho capítulo en mi libro Escultura gótica en León y provincia $(1230-1530)^{22}$.

Sin embargo, como advierte la citada investigadora, la fórmula de la portada, creada en Senlis, y renovada en NotreDame de París, será la que se imponga y se repetirá a lo largo de la Edad Media. La Coronación de la Virgen de Senlis es el ejemplo más antiguo donde se encuentra en el centro de la fachada de una catedral. En las portadas dedicadas a este asunto, la Muerte y la Asunción de la Virgen figuran en el dintel: Mantes, Chartres, Amiens, Estrasburgo.... etc. En Senlis lleva un libro y un cetro; en Chartres se inclina ante el Salvador ya coronada. En portadas posteriores, en un proceso evolutivo con modalidades intermedias, como Cristo coronando a su Madre, son los ángeles los encargados de coronar a María. La Virgen concebida como regina coeli y esposa de Cristo adquiere su forma visual en las portadas de las catedrales góticas: Hodie coronatur y hodie collocatur in throno a dextris Dei, se lee en un sermón para la fiesta de la Asunción de la Virgen en un leccionario del siglo XII en Compiègne, procedente de la abadía de SaintCorneille. Las letanías de la Virgen asimilan a ésta con el arca de la alianza. La Coronación de la Virgen se emplaza en el lugar de honor del tímpano. Desde las grandes catedrales de Francia, la más teológica de las cuales es Chartres, pasando por Amiens, París, y un larguísimo etcétera, se extiende

${ }^{21}$ M.-L. THÉREL, A l'origine du décor du portail occidental de Notre-Dame de Senlis: le Triomphe de la ViergeÉglise. Sources historiques, littéraires et iconographiques, París, 1984, p. 3.

22 Á. FRANCO MATA, Escultura gótica en León y provincia (1230-1530), cit. pp. 179-202. la iconografía mariana al resto de Europa ${ }^{23}$. Aunque se importan los grandes programas iconográficos, conviven con las formas del arte nativo, originándose simbiosis llenas de originalidad.

Aunque el título de Regina Coeli se remonta a los primeros siglos de la Iglesia, será Justiniano quien generalice el uso de la diadema o corona ${ }^{24}$. El tipo evolucionará paulatinamente hacia un amplio repertorio de coronas en la escultura gótica, rematadas en almenillas escalonadas, motivos vegetales, como hojarasca, donde destacan las Schöne Madonnen alemanas de Peter Parler ${ }^{25}$, pencas, trebolados, o fitomorfos, como flordelisados, alcanzando a veces alturas descomunales, como en Navarra.

La vinculación de la Virgen a la Iglesia es tema de larga tradición, elaborado por los Santos Padres en el marco de la vida espiritual, que ha sido glosado con su proverbial sensibilidad por Hugo Rahner, en diez capítulos: María, modelo y compendio de la Iglesia, Inmaculada, Siempre Virgen, Madre de Dios, Madre de los creyentes María en la fuente bautismal, Crecimiento del corazón, la Mujer fuerte, Espíritu y Corazón, la Mujer del Apocalipsis, Asunción ${ }^{26}$.

La devoción mariana se extiende por Castilla desde la época de Alfonso VIII,

-

${ }^{23}$ P. WiLliamsON, Escultura gótica 1140-1300 (1995), Madrid, 1997.

${ }^{24}$ E. SANDBERG VAVALÁ, L'iconografia della Madonna col Bambino nella pittura italiana del Duegento, Roma, 1983, cita un ejemplar de Santa Maria in Trastevere con la Virgen coronada derivada del mosaico de Teodora, de San Vital de Ravena, además de un cetro en su mano derecha, tav. I, c.

${ }^{25}$ Die Parler und der schöne Stil 1350-1400. Europäische Kunst unter den Luxemburgern, exposición Schnütgen-Museum, comisario A. LEGNER, Colonia, 1978, catálogo, 3 vols., A. LEGNER y S. CZYMMEK, Die Parler und der schöne Stil 1350-1400. Europäische Kunst unter den Luxemburgern, con la colaboración de E. WELLERSHOFF, Colonia, 1978.

${ }^{26}$ H. RAHNER, María y la Iglesia. Diez capítulos sobre la vida espiritual (1950), Bilbao, 1958, Madrid, 2002. 
aunque las órdenes religiosas de nueva creación, cistercienses, franciscanos, premonstratenses y dominicos fundamentalmente, pudieron contribuir a su expansión. Se amplían las advocaciones marianas y patronazgos por todo el territorio ${ }^{27}$. Algunas advocaciones son citadas en las Cantigas, como la Virgen de Villasirga, Santa María de Salas y Santa María de la Arrixaca, en Murcia, tienen su referencia plástica, como he puesto de manifiesto hace algunos $\operatorname{años}^{28}$. La mayor parte de las esculturas son obra de imagineros locales. J. Ara recoge una interesante referencia de la General Estoria, donde se dice: "E aún dicen que era Thare entallador dellos, e que facie él aquellas imágenes e que las vendia como facen hoy algunos de sus imágenes de los nuestros santos $e$ entalladuras dotras cosas en muchas figuras e las dan por dineros" ${ }^{29}$. Conocemos descripciones del siglo XIII, como la del Milagro XIV de Gonzalo de Berceo con su habitual gracejo: "En esti monasterio que avemos nomnado/ avie de buenos monges buen convento provado / altart de la Gloriosa rico e mui onrado I en el rica imagen de precio muy granado. I Estaba la imagen en su trono posada / so fijo en sus brazos, cosa es costumnada / los reis redor ella, sedie bien compannada / como rica reina de Dios santificada. / Tenie rica corona como rica

-

${ }^{27}$ Para este tema vid. Oraciones a la Virgen María. Guía y mapa de España con los lugares dedicados al culto de la Virgen, 2ª ed., Madrid, 1978.

${ }^{28}$ Á. Franco MATA, "Las Cantigas de Santa María de Alfonso $X$ el Sabio. Texto e Imagen. Música. Relaciones con la plástica y la pintura", La Città e il Libro: II Il manoscritto. La miniatura, Convengno internazionale, Accademia delle Arti del Disegno Firenze, dal 4 al 6 settembre 2002/ The city and the Book II. The manuscript, the illumination. International Conference, Accademia delle arti del Disegno, Florence, 4-6 september 2002; Id. "Las Cantigas de Santa María. Texto, imagen, música. Relaciones con la escultura y la pintura", Ars Longa Vita Brevis. Homenaje al Doctor Rafael Sancho de San Román, Toledo, 2006, pp. 209-242. Id. La Virgen de la Arrixaca, en Murcia. Vinculaciones con las Cantigas de Alfonso X el Sabio (en prensa).

${ }^{29}$ Ed. Solalinde, cap. IX, p. 89, cfr. C. J. ARA GIL, Escultura gótica en Valladolid y sus provincia, cit. p. 127. reina / de suso rica impla en logar de cortina / era bien entallada de lavor mui fina / valie mas essi pueblo que la avie vecina" ${ }^{\prime 30}$. La Cantiga 388 del rey Sabio dice que las imágenes de la Virgen "son muy apostas e fermosas, na testa, para parecer mellor coronas con muites pedras ricas que gran esplendor daban" ${ }^{31}$. También las Cantigas refieren la colocación de la Virgen con el Niño sobre la puerta de las iglesias, así la Cantiga 292 dice: “E quand algua ciudade se mouros ya ganar sa imagen na mezquita ponya e o portal", e incluso sobre la puerta de las ciudades dentro de una hornacina $^{32}$.

De comienzos del siglo XIII e incluible en el "arte 1200", es la esplendorosa imagen conocida bajo la advocación de Santa María de Toledo, conservada en la vitrina 3 de la sacristía de la Catedral Primada y anteriormente en el Tesoro, razón por la cual también es llamada Virgen del Tesoro $^{33}$. La justificación de incluirla en el presente contexto es que coincide con la talla gótica en algunos extremos de carácter teológico, que analizaré más adelante. Se trata de una imagen de la Virgen entroni-

${ }^{30}$ GONZALO DE BERCEO, Milagros de Nuestra Señora (1985), ed. de Michel Gerli, Madrid, Cátedra, 13 $3^{\underline{a}}$ ed. 2006, pp. 126-128. En la edición del Ayuntamiento de Logroño, GONZALO DE BERCEO, Obras Completas, Logroño, 1971, correspondería a la p. 147, pero se ha saltado el Milagro XIV; C. J. ARA GIL, Escultura gótica en Valladolid y su provincia, cit. p. 127.

${ }^{31}$ Cfr. C. J. ARA GIL, Escultura gótica en Valladolid y su provincia, cit. p. 128.

${ }^{32}$ C. J. ARA GIL, Escultura gótica en Valladolid y su provincia, cit. p. 128.

${ }^{33}$ Es de madera y plata, gemas, rubíes, esmeraldas y zafiros, y sus medidas: Alt. $82 \mathrm{~cm}$.; ancho: $27 \mathrm{~cm}$.; grueso: 33. CONDE DE CEDILlO, Catálogo Monumental y Artístico de la Catedral de Toledo (Madrid, 1919), Introducción y Notas de M. Revuelta Tubino, Toledo, 1991, p. 159, n. 15; J. F. RIVERA RECIO, Guía de la Catedral de Toledo, Toledo, 1949, p. 37, n. 97; Inventario Artístico de Toledo. Tomo II. La Catedral Primada, dir. M. RevUELTA TUBINO, Madrid, 1989, (vol. I), p. 342, foto 163; R. Ramírez De ARellano, Estudios sobre la historia de la orfebrería toledana, Toledo, 1915; Á. FRANCO MATA, “Santa María de Toledo", Inmaculada. cit. pp. 64-66. 
zada con el Niño en brazos, chapada en plata sobre alma de madera por multitud de clavos distribuidos por toda la superficie. El asiento primitivo ha sido sustituido por un silloncito barroco, el primero de ellos susceptible de ser reconstruido a través de paralelos hispánicos conservados. Es el caso de la Virgen de Villatuerta (Navarra), ejemplar derivado de la titular de la catedral de Pamplona, formado por estructuras laterales rectangulares con bordes resaltados por cenefas decoradas con filigrana y piedras preciosas, y en el interior dos arquitos que cobijan a uno y otro costado la Anunciación y Visitación respectivamente $^{34}$. La Virgen viste saya rozagante de finísimos pliegues paralelos pegados al cuerpo, insinuándose las formas pectorales por medio de estructuras circulares. Sobre las mangas ajustadas de la camisa se disponen las voluminosas mangas de la saya rematadas en una cenefa de bordes perlados y una fila de rombos, todo resaltado en relieve. Bajo la túnica asoman los zapatos decorados por grupos de bolitas triples y una tira vertical perlada. Se cubre con manto sujeto en el cuello por aproximación forzada, como dos siglos más tarde la Virgen de la Merced de Pere Moragues. Bajo el cierre se aprecia la huella del desaparecido broche de estructura escutiforme. Cubre la cabeza con un velo de bordes en zigzag, modalidad que en ejemplares navarros, como la Virgen de la catedral de Pamplona y la de Irache, se sustituye por una toca. Ostenta corona de filigrana de finos hilos, articulada, con charnelas y decorada con gemas, rubíes, esmeraldas y zafiros.

El Niño, emplazado frontalmente sobre el regazo de María, viste saya talar de pliegues paralelos cubierta parcialmente por el manto. Bendice con la diestra en tanto apoya sobre la rodilla izquierda el libro

\footnotetext{
${ }^{34}$ C. FERNÁNDEZ-LADREDA, Imaginería medieval mariana en Navarra, Pamplona, 1988, pp. 42-58.
}

cerrado sobre cuya tapa se lee en tres líneas: ihs, en caracteres minúsculos latinos, $x p s$, en griego y debajo A(alpha) $\mathrm{O}$ (mega), referencia directa a Cristo como Sabiduría total, principio y fin, síntesis del texto juaneo de la gran filacteria que porta el Niño del espléndido ejemplar de Irache, que después de la antífona de Navidad, dice: Ego sum alpha et omega, primus et novissimus dominus. Ello, junto al simbolismo del material, confieren a la obra un carácter metafísico, divino, que trasciende la realidad terrena para inscribirse en ambiente ultraterreno, donde el brillo y luminosidad de la plata prestan a la obra el continente intemporal que caracteriza este tipo de imágenes sagradas.

La disposición de los dos personajes responde al tipo de Virgen como "trono de la Sabiduría", que es Cristo. Aunque analizado el tipo en ejemplares de madera ${ }^{35}$, es extrapolable con toda justificación a un material noble como la plata. Los ejemplos son numerosos en el arte románico y perviven durante el primer arte gótico, en que se inicia la humanización de los dos personajes, como se evidencia en el ejemplar toledano, encuadrable en el arte 1200, con ostensible influencia bizantina ${ }^{36}$. Ambos personajes tienen rostro y manos de madera repintada en época posterior, como la corona que luce el Niño, un grueso aro cilíndrico basto, que imita lejanamente la corona de la Virgen.

El conjunto es de completo bulto redondo, derivado tal vez del ejemplar titular de la catedral de Pamplona, del que se ha perdido el Niño, sustituido por uno barro-

\footnotetext{
35 A. D. MCKENZIE, The Virgin Mary as the Throne of Salomon in Medieval Art, Nueva York, 1965; I. FORSYTH, The Throne of Wisdom Wood Sculpture of the Madonna in romanesque France, Princeton, 1972;.

36 Á. FRANCO MATA, “Arte 1200: iconografía y función de los "Ormamenta ecclesiae" hispánicos", Actes, Colloque international organisé par le Service de la Culture de la Province de Namur dans le cadre de l'exposition Hugo d'Oignies, Namur, 2005, pp. 223-244.
} 
co, y el trono, por uno neorrenacentista del siglo XIX. La obra toledana resulta algo más evolucionada, pero no muy lejana en fecha. Aunque no conocemos documentación que acredite que la imagen fuera empleada en procesiones, como la Virgen de Pamplona, el hecho de haber sido tallada en bulto redondo es un argumento a favor. No es fácil determinar si, como la Virgen de Pamplona, se ideó como imagen relicario, en cuya cabeza se sitúa un compartimiento para cumplir tal función. En la Virgen toledana no se aprecia en la superficie ningún orificio; tal vez se dispusiese en la parte superior de la cabeza, como en un ejemplar de madera procedente de Auvernia, actualmente en el Museo Arqueológico Nacio$\mathrm{nal}^{37}$, bajo la corona, pero ésta aparece fija, y en consecuencia, difícil de verificar. Nuestra Señora de la Majestad de la catedral de Astorga alberga un receptáculo con reliquias variadas, descubierto en una reciente restauración ${ }^{38}$.

El tipo de la Virgen sedente es el que se impone en los siglos XIII y XIV, con continuidad en el XV. La talla de la Institución granadina está sentada sobre un banco sin respaldo, con molduras adornando los laterales. María viste saya rozagante, rasgo que no se aprecia al estar sentada; dicho atuendo responde a la evolución de la moda. En ocasiones, como en el tipo vasco-navarroriojano, y sus derivaciones, ostenta un medallón decorado en relieve. Sobre ella dispone el manto, invariablemente cruzado de izquierda a derecha sobre el regazo, a veces

\footnotetext{
${ }^{37}$ Á. FRANCO MATA, “Panorama general del románico español a través de los fondos del Museo Arqueológico Nacional", Arte Románico en Madrid. Enciclopedia del Románico, Aguilar de Campoo, Centro de Estudios del Románico, 2008, pp. 123-281, sobre todo pp. 192-193.

${ }^{38}$ J. PÉREZ GIL, “Imago Maiestatis Marie: Vírgenes románicas de metal y repujadas en las diócesis de Astorga y León", XX Ruta Cicloturística del Románico Internacional, 3 febrero-16 de junio, 2002, Poio, pp. 110111.
}

sujeto con el fiador de cuerda, elemento derivado del atuendo utilizado por personajes regios y nobles que se trasvasa a los dominios de la escultura monumental y yacentes funerarios. Este elemento es frecuente en imágenes del último tercio del siglo XIII. Otra prenda típica que lleva la Virgen es el velo o impla, sostenido por la corona real. El velo tuvo significación sagrada desde los comienzos del cristianismo, puesto que era de uso por parte de las doncellas que se consagraban a Dios. Era prenda obligada en las damas de alcurnia, ya que estaba vedada la exhibición de la cabeza en aras de evitar la sensualidad. Calza zapatos de aguda punta. La actitud de las manos varía; la izquierda suele presentar tres posturas, o bien va colocada sobre el hombro del Niño, o lo sostiene lateralmente o levanta el manto como resguardándole. La mano derecha se mantiene generalmente levantada con los dedos extendidos hacia arriba para mostrar un objeto, que suele ser una flor o un fruto, una manzana.

La flor, que en ocasiones muestra la Virgen en su mano derecha, es asociada por Gonzalo de Berceo en los Milagros de Nuestra Señora con un bellísimo jardín, en el que las flores pueden ser consideradas como los distintos apelativos con que se las denomina, y los frutos como sus milagros, describiendo algunos de ellos: "Dessuso lo dessiemos que eran los frutales / en que facien las aves los cantos generales / los sus sanctos miraclos grandes e principales / los cuales organamos nenas fiestas caubdales" ${ }^{\prime \prime}$.

La manzana, que, paradójicamente no es mencionada en el Génesis, donde sólo se habla de fruto, su simbología, sin embargo, debía de ser muy clara. La manzana es mencionada en la liturgia visigótica en el prefacio de la misa de la Asunción: [María] "no conoció el daño ocasionado por la de-

\footnotetext{
${ }^{39}$ Cfr. C. J. ARA GIL, Escultura gótica en Valladolid y su provincia, cit. p. 129.
} 
gustación prohibida, ya que esta virgen nuestra no consintió como Eva en el engaño de la serpiente. Esta, por la manzana del árbol prohibido, propinó amargura a toda la humanidad. Aquélla, por la dulzura del árbol de la vida, acaricia ya las entrañas de los nuevos hijos". La antífona de aleluya de la fiesta de María insiste en dicha mención: "Huerto cerrado, hermana mía, esposa mía, fuente, paraíso con frutos de manzana sellado" $^{\prime 4}$. Lo que interesa es la consideración a María como antítesis de Eva, establecida desde el punto de vista teológico por San Justino $(+165)^{41}$. Él y posteriores escritores enfatizan la antítesis incluyendo a la serpiente engañadora. También la doctrina pontificia utilizó la manzana como símbolo para representar el fruto envenenado. El papa Inocencio III (1198-1216), en una homilía compuesta para la Natividad de María repite casi las mismas ideas. "Aquélla asintió al diablo y comió la manzana prohibida; ésta, María, creyó y concibió al Hijo prometido. Aquélla comió la manzana para la muerte. Esta concibió al Hijo para la salvación" ${ }^{42}$.

Los poetas también se hacen eco de dicho antagonismo. Berceo se expresa así: "Los que por Eva fuemos / en perdicion caidos / por ella [María] recobramos los solares perdidos. Si por Ella non fuesse / yazriémos amortidos / mas el so sancto fructo / nos ovo redemidos / ... Por el so sancto fructo / que Ella concibio" ${ }^{43}$. "El fruto de los arbores era duez e sabrido / si don Adam oviese de tal fructo comido / de

${ }^{40}$ J. IBÁÑEZ y F. MENDOZA, María en la liturgia hispánica, Pamplona, 1975, p. 238, cfr. M. GÓMEZ RASCÓN, Theotókos, cit. p. 29.

${ }^{41}$ J. LAPORTE, Los Padres de la Iglesia. Padres griegos y latinos en sus textos (2001), Madrid, San Pablo, 2004, pp. 15-39.

${ }^{42}$ Doctrina Pontifica. T. IV. Sermón de la Natividad de la Virgen María, Madrid, 1954, p. 54.

${ }^{43}$ G. DE BERCEO, Milagros de Nuestra Señora, Obras Completas, Logroño. tan mala manera non seria decibido / ni tomarien tal danno Eva ni so marido". Por su parte, el gran trovador de Santa María le dedica estos loores de contraste con Eva en la poética lengua gallega: "Entre Ev'e Eva, gran department'a / ca Eva nos tolleu / o Paray's de Deus. / Ave nos y meteu; Porend, amigos meus: entre Av'e Eva" ${ }^{44}$, idea preconizada siglos antes por Venancio Fortunato (+ 601): “Lo que la desdichada Eva nos robó / tú nos lo devuelves en tu fruto santísimo $^{\prime 45}$. La trayectoria iconográfica de dicha antítesis ha sido analizada magistralmente por Ernst Guldan en su clásico libro Eva und Maria. Eine Antithese als Bildmotiv $^{46}$. La escultura monumental gótica se hace eco de esta antítesis, así la imagen del parteluz de la portada derecha de la catedral de Amiens, de h. 1220-1230, con la peculiaridad de la representación de la creación de Eva y la recriminación de Dios a Adán, y la Virgen con el Niño, de la portada norte de la catedral de Notre Dame, de París, de h. $1250^{47}$, y la Virgen Blanca de la catedral de León, que tanta dependencia tiene de la obra francesa ${ }^{48}$. Dicha iconografía pasa a la imaginería, como se advierte en otra imagen de la localidad leonesa de Cabreros del Río ${ }^{49}$.

El Niño Jesús, sobre su regazo, aparece sentado o de pie. En la primera postura puede adoptar diversas actitudes, bien completamente frontal, herencia directa de las Vírgenes románicas, donde se enfatiza

${ }^{44}$ Cantigas de Loor, LX.

${ }^{45}$ F. AROCENA, Los himnos de la liturgia de las Horas, Madrid, 1992, p. 341. Ver B. Velado GRAÑA, Himnos de la liturgia de las horas (1984), Barcelona, 1988.

${ }^{46}$ E. Guldan, Eva und Maria. Eine Antithese als Bildmotiv, Graz-Colonia, 1966.

${ }^{47}$ W. SAUERLÄNDER, Sculpture gothique en France..., cit. láms. 168, 188

48 Á. FRANCO MATA, Escultura gótica en León y provincia (1230-1530), cit. pp. 298-301.

49 Á. FrANCO MATA, “Una Virgen gótica, de ascendencia alemana, en Cabreros del Río", Diario de León, 3 de julio de 1985, p. 32. 
la figura de la Virgen como Sedes Sapientiae. Lo más frecuente, sin embargo, es aparecer sentado sobre la rodilla izquierda de la Virgen, colocando sus pies sobre la derecha, imprimiendo un ligero giro al cuerpo. Viste túnica talar y eventualmente manto de cuerda. En los ejemplos más antiguos pervive la corona regia, atributo frecuente en las imágenes románicas, pero en la mayor parte de las esculturas góticas se presenta con la cabeza descubierta. A diferencia de la Virgen lleva los pies descalzos. A veces porta la esfera del mundo, atributo que convive con el libro, abierto o cerrado. Ambos atributos que confluyen en la persona de Cristo, no son excluyentes, sino complementarios. Esta es la razón, en mi opinión, de que en el mismo tipo iconográfico aparezca indistintamente uno $\mathrm{u}$ otro elemento. Por el libro se designa a Cristo como luz del mundo, el Todopoderoso; por la esfera, se presenta como el dominador del mismo.

Cristo-Niño suele llevar un libro con un texto joánico, o bien alusivo a su evangelio o bien al Apocalipsis. En el primero de los casos sería Ego sum lux mundi, como en el Cristo majestad y en el grupo escultórico de la Virgen entronizada con el Niño de Ger, ambos del Museu Nacional d'Art de Catalunya, de Barcelona ${ }^{50}$. Dicho texto vincula ambas obras con la liturgia de la misa, ya que en la Edad Media y hasta antes de la última reforma del Concilio Vaticano II se rezaba al finalizar la misa. En la Virgen románica de Irache conviven dos textos, uno mariano, alusivo a la Natividad y el otro al Apocalipsis, "Puer natus est nobis, venite adoremus. Ego sum alpha et omega, primus et novissimus dominus", que en la Virgen de Toledo, se resume en las dos letras A y O. Se trata del texto apocalíptico (Ap. 1,

-

50 "Pantocrátor, de San Clemente de Taüll", p. 58, fig. 35; J. CAMPS, "Imagen de la Virgen de Ger", Museu Macional d'Art de Catalunya, Prefiguración, cit. pp. 149150.
8) de Juan, antes de dirigir el mensaje a cada una de las siete iglesias de Asia, si bien se simboliza en él a la Iglesia universal. El autor se dirige a ellas para reavivarlas en la fe, amenazada en algunos casos, al parecer, por doctrinas y actitudes extrañas, y para infundirles ánimo en medio de las dificultades y persecuciones que ya están sufriendo o que él prevé que van a sufrir muy pronto. Les muestra cómo el juicio de Dios, que salva o condena, dando a cada uno "según lo que haya hecho", comienza a realizarse hoy en la historia presente. La segunda parte del texto figura en la filacteria que porta el Niño en el tríptico gótico firmado por Juan Hispalense (1420), que se custodia en el Museo Lázaro Galdiano, de Madrid, lo que pregona su larga perviven$\mathrm{cia}^{51}$. El Apocalipsis fue un libro muy leído durante la Edad Media, y ya desde época temprana se hicieron comentarios, como el de Cesáreo de Arlés y sobre todo el del monje Beato de Liébana, en la segunda mitad del siglo VIII. Los asombrosos textos dieron lugar a la ejecución de imágenes de impactantes colores planos y contrastados llenos de fuerza y energía. De su importancia y obligatoriedad de lectura en los monasterios entre Pascua y Pentecostés da fe la pena de excomunión a que se veían sometidos quienes no cumplieran el mandato. Aunque se inscribe en la liturgia hispánica, la enseñanza pervive durante la Edad Media, como se pone de manifiesto en las apocalípticas imágenes, en Navarra, cuyos monasterios, junto a La Rioja, León y Castilla se presentan como pioneros.

En mi opinión, bien pudo ser la referencia a Él como el Alfa y la Omega y las características formales presentes en la imaginería navarra, las que confieren este carácter intemporal que proporciona la idea

51 .- E. PAReja López y M. MEgÍA NAVARRO, El arte de la reconquista cristiana. Historia del Arte en Andalucía, vol. III, Sevilla, 1998, pp. 412-415. 
de Principio y Fin, que figura en ocasiones en el libro de Cristo. De hecho, Cristo en majestad, presidiendo las grandes portadas románicas, se manifiesta como Teofanía intemporal, como acertadamente han demostrado Yves Christe y Peter Klein. Dicha presencia perdura en los programas monumentales góticos del siglo XIII, como en la portada del Sarmental de la catedral de Burgos, Santa María de Sasamón, y la portada central meridional de la catedral de León, entre otras ${ }^{52}$.

Aunque la iconografía de Vírgenes entronizadas con el Niño responde a unos tipos comunes en todo el ámbito hispano, una revisión de las mismas en las distintas provincias, como Asturias ${ }^{53}$, Ávila ${ }^{54}$, Cataluña ${ }^{55}$, León ${ }^{56}$, Valladolid ${ }^{57}$, Palencia ${ }^{58}$, Navarra $^{59}$, me han llevado a proponer la procedencia de la Virgen del Instituto Gómez Moreno, siempre en el terreno de la hipótesis, de la provincia de León, pero dependiente estilísticamente de Navarra.

Creo oportuno efectuar un breve $e x$ cursus sobre la imaginería de Navarra, que espero dé luz sobre algunos aspectos de interés en el presente contexto. Es una de las provincias españolas con mayor canti-

\footnotetext{
52 Á. FRANCO MATA, Escultura gótica en León y provincia (1230-1530), cit. pp. 65-83.

${ }^{53}$ P. PANIAGUA FÉLIX, "Virgen sedente", Orígenes. Arte y cultura en Asturias. Siglos VII-XV, catálogo exposición, Oviedo, pp. 443-444, n. 266.

${ }^{54}$ Á. Franco MATA, Escultura gótica en Ávila, Ávila, 2004 .

55 Museu Nacional d'Art de Catalunya, Prefiguración, Barcelona, 1992.

${ }^{56}$ M. GÓMEZ RASCÓN, Teothokos, cit.

${ }^{57}$ C. J. ARA GIL, Escultura gótica en Valladolid y su provincia, cit. pp. 126-149.

${ }^{58}$ Como he indicado, P. LUIS HUERTA está realizado una tesis doctoral sobre dicho tema.

59 C. FERNÁNDEZ-LADREDA, Iconografía medieval mariana en Navarra, Pamplona, Gobierno de Navarra, 1989; Id. "La Edad Media", Salve. 700 años de arte y tradición mariana en Navarra, catálogo exposición, Pamplona, 1994, pp. 25-31.
}

dad de imágenes marianas entronizadas. $\mathrm{C}$. Fernández Ladreda contabiliza cuarenta y nueve románicas y cincuenta y nueve góticas. Interesa destacar el tipo denominado vasco-navarro-riojano, que se extiende por las citadas provincias, y contiene a su vez dos subgrupos, el primero de los cuales es el definidor del tipo: a) Los Arcos, Miranda de Arga, Arizaleta, Fitero (Lám. 6), Berbinzana, Mendigorría, Artaza y Ubago. b) Estella (San Pedro de la Rúa), Puente la Reina (Santiago), Olite, Artajona, Azagra, Cárcar, San Adrián, Eransus, Echávarri y Arzoz. C) Estella (Santa María del Puy), Estella (Santa María de Jus del Castillo), Bargota, Orísoain, Eriete y Mélida. Se trata de imágenes muy esbeltas de facciones delicadas, lucen espléndida corona, exhiben un gran broche circular y tienen manto encordado formando un agudo ángulo. El velo forma pliegues zigzagueantes, y deja asomar ligeramente el cabello. Con la mano derecha sostiene bien una flor o una manzana y con la izquierda sujeta al Niño por el hombro. El Niño que apoya el pie derecho sobre el muslo correspondiente de la Virgen bendice con la derecha y con la izquierda sostiene el libro generalmente cerrado. No lleva corona. Los caracteres citados se repiten en los demás grupos, el fiador puede ser anguloso o arqueado. Establece además otro grupo de tallas relacionadas con el tipo, subdividido a su vez en tres subgrupos: a) Ecala, Torralba (Codés), Cintruénigo, Lerín y Genevilla. B) Galdeano. c) Urbiola, Tulebras, Bargota (Poyo) y Lizaso. Tanto la disposición como los atributos permanecen invariables. La evolución se inclina hacia la industrialización.

La Virgen del Instituto Gómez Moreno resume los caracteres más representativos de las Vírgenes entronizadas de la etapa plenamente gótica. Coincide la disposición con las imágenes navarras, que corresponden en línea de máxima al tipo $3^{\circ}$ de la tipología establecida por J. Ara, pero con elementos del grupo $2^{\circ}$, como la Virgen con 
el manto encordado y el broche circular y el Niño portador de la esfera, no del libro, como indica para el grupo $3^{\circ}$. Dicha investigadora, sin embargo, incluye algunas variantes en el grupo $3^{\circ}$, que coinciden con la imagen en análisis, como un ejemplar del Museo Diocesano y Catedralicio, procedente de Fombellida ${ }^{60}$. Por el contrario una Virgen del mismo museo, procedente de zona leonesa, presenta similares caracteres, con la salvedad de que el Niño lleva una granada, símbolo del amor de Cristo ${ }^{61}$.

Hace algunos años M. Gómez Rascón ha apuntado la posibilidad de que la bellísima talla de Santa María la Real, del monasterio cisterciense de Gradefes (León), sea una importación de Navarra o La Rioja, considerando que el monasterio inició la reforma con monjas venidas del de Tulebras, el año $1168^{62}$. Aunque repintada en época renacentista, no ha perdido su elegancia original (Lám. 8). Va ataviada de acuerdo con los cánones de las Vírgenes entronizadas, luciendo un velito de pliegues zigzagueantes, que deja asomar cabellos de estructura sogueada, con la mano derecha sostiene una manzana y con la izquierda sujeta al Niño por el hombro. El manto está sujeto con fiador de gruesas

\footnotetext{
${ }^{60}$ C. J. ARA GIL, Escultura gótica en Valladolid y su provincia, cit. p. 140, lám. LIX, 3.

${ }^{61}$ C. J. ARA GIL, Escultura gótica en Valladolid y su provincia, cit. p. 140, lám. LIX, 2.

${ }^{62}$ M. GÓMEZ RASCÓN, Theotokos, cit. p. 104, lám. 117. Para la historia y arte del monasterio vid. M. Gómez MORENO, Catálogo Monumental de España. Provincia de León, Madrid, 1926, ed. facsimilar, León, Nebrija, 1979, pp. 418-422, sobre todo p. 421; A. CALVO, El Monasterio de Gradefes. Apuntes para su historia y la de algunos otros cenobios y pueblos del concejo, León, (1936-1945), ed. facsimilar, 1984, pp. 151-412, sobre todo pp. 223-224. Este autor cita otra imagen de la Virgen, y la duda de a cuál de las dos se refiere como imagen milagrosa. La imagen del "Monasterio de las Bernardas de Gradefes" figura en las Relaciones existentes entre la Santísima Virgen y las religiosas del Cister, sacada en su mayor parte de los escritos de los Antiguos Bernardos Españoles.
}

líneas en arco. El Niño dispone los pies al modo de las imágenes navarras, con la diestra bendice y con la izquierda sostiene el libro abierto. Peina el cabello de forma similar al de la talla del Instituto Gómez Moreno. El artífice de la talla está relacionado con los escultores de la catedral de León, como se observa en otras dos tallas, la Virgen y San Juan, procedentes de un Calvario, actualmente en el Museo Arqueológico Nacional $^{63}$. Tanto la Virgen del monasterio de Tulebras, como la de Urbiola y la de Bargota, presentan similitudes con la talla granadina. Esta y la de Tulebras ostentan un grueso fiador en ángulo. La alta corona también remite a Navarra.

Recientemente C. Fernández-Ladreda ha llamado la atención sobre la influencia de tipo mariano vasco-navarro-riojano sobre Burgos, Palencia, Valladolid, Soria, Segovia y León, con argumentos exclusivamente de orden tipológico ${ }^{64}$. Entre vacilaciones y titubeos se decide por el origen tipológico en Burgos, extremo para el que no encuentro argumentos de peso. Yo creo que se trata de un tipo formado en Europa sin todos los elementos componentes, importado en Navarra, donde se consolidó. La Virgen mosana, de estilo 1200, de hacia 1210-1220, hoy en la Liebiehaus de Frankfurt de Meno, es una Virgen entronizada coronada, luciendo un broche circular, con una manzana en su mano, sosteniendo al Niño ladeado, que bendice y sostiene un libro $^{65}$. En cuanto al fiador yo estimo que

\footnotetext{
${ }^{63}$ Á. Franco MATA, Museo Arqueológico Nacional. Catálogo de la escultura gótica (1980), 2 ${ }^{\underline{a}}$ ed., Madrid, 1993.

${ }^{64}$ C. FERnÁNDEZ-LADREDA, "Algunas reflexiones en torno a las vírgenes del llamado tipo vasco-navarroriojano", La catedral de León en la Edad Media, Actas del congreso internacional, León, 2004, pp. 623-636.

65 K. HOFFMANN, "Virgin and Child", The Year 1200. A Centennial Exhibition at The Metropolitan Museum of Art. I. The Exhibition. Catalogue Nueva York, The Cloisters Studies in Medieval Art I. The Metropolitan Museum of Art, 1970, pp. 97-98, n. 105.
} 
tiene su raíz en la escultura monumental francesa, de donde es adoptada en la escultura funeraria y en la imaginería. Navarra tenía relaciones ultramontanas seculares; sirva de ejemplo la esmaltería. Su importancia artística destaca tanto en el románico como en el gótico, y algunos elementos del atuendo mariano, como la toca, que C. Fernández Ladreda estima como excepcionales en la provincia, no lo son tanto. Así lo ponen de manifiesto la Virgen tardorrománica del claustro de la catedral de León, Nuestra Señora de la Majestad de la catedral de Astorga ${ }^{66}$, y parcialmente la de la iglesia de Nuestra Señora de la Llama, de Cerezo de Riotirón (Burgos), de hacia 11801190, actualmente en The Metropolitan Museum de Nueva York ${ }^{67}$.

Al dato aportado por Gómez Rascón a propósito de las relaciones de Gradefes con Navarra-La Rioja, yo agrego el siguiente: la similitud, sobre todo facial y la disposición general de la imagen, de Nuestra Señora de Sandoval ${ }^{68}$ (Lám. 7), monasterio no lejos de Gradefes, con la imagen del Instituto Gómez Moreno. En la ribera de Gradefes, a $15 \mathrm{~km}$. de esta villa, se emplazaba el monasterio benedictino de Eslonza, del que sólo pervive la portada, que ha sido trasladada a León ${ }^{69}$. Quizá se fundiera con éste, el también desaparecido cercano a Pesquera $^{70}$. Un monasterio se cita en la localidad de Valdepolo ${ }^{71}$ y también los de Vega de Monasterio y de San Juan de Vega ${ }^{72}$, el primero de los cuales estaba dedicado a

${ }^{66}$ B. VELAdO GRAÑA, “Nuestra Señora de la Majestad", Salve Regina..., cit. pp. 13-14

${ }^{67}$ K. Hoffmann, "Adoration of the Magi", The Year $1200 \ldots . . .$, cit. pp. 43-44, n. 51.

${ }^{68}$ M. GÓMEZ RASCÓN, Theotokos, cit. p. 224, lám. 101. Vid. también M. GóMEZ MORENO, Catálogo Monumental de España. Provincia de León, cit. pp. 422-426, sobre todo p. 425.

${ }^{69}$ A. CALvo, El Monasterio de ...., cit., pp. 36-38

${ }^{70}$ A. CALVO, El Monasterio de ..., cit. pp. 103-104.

${ }^{71}$ A. CALVO, El Monasterio de ..., cit. pp. 115-116.

${ }^{72}$ A. CALVO, El Monasterio de ..., cit. pp. 121-126.
Santa María. Aunque en origen era de benedictinos, a partir del siglo XIV parece que estuvo habitado por religiosas. La citada advocación indica que hubo de tener una imagen de la Virgen. ¿Sería la "granadina" que ahora se analiza?

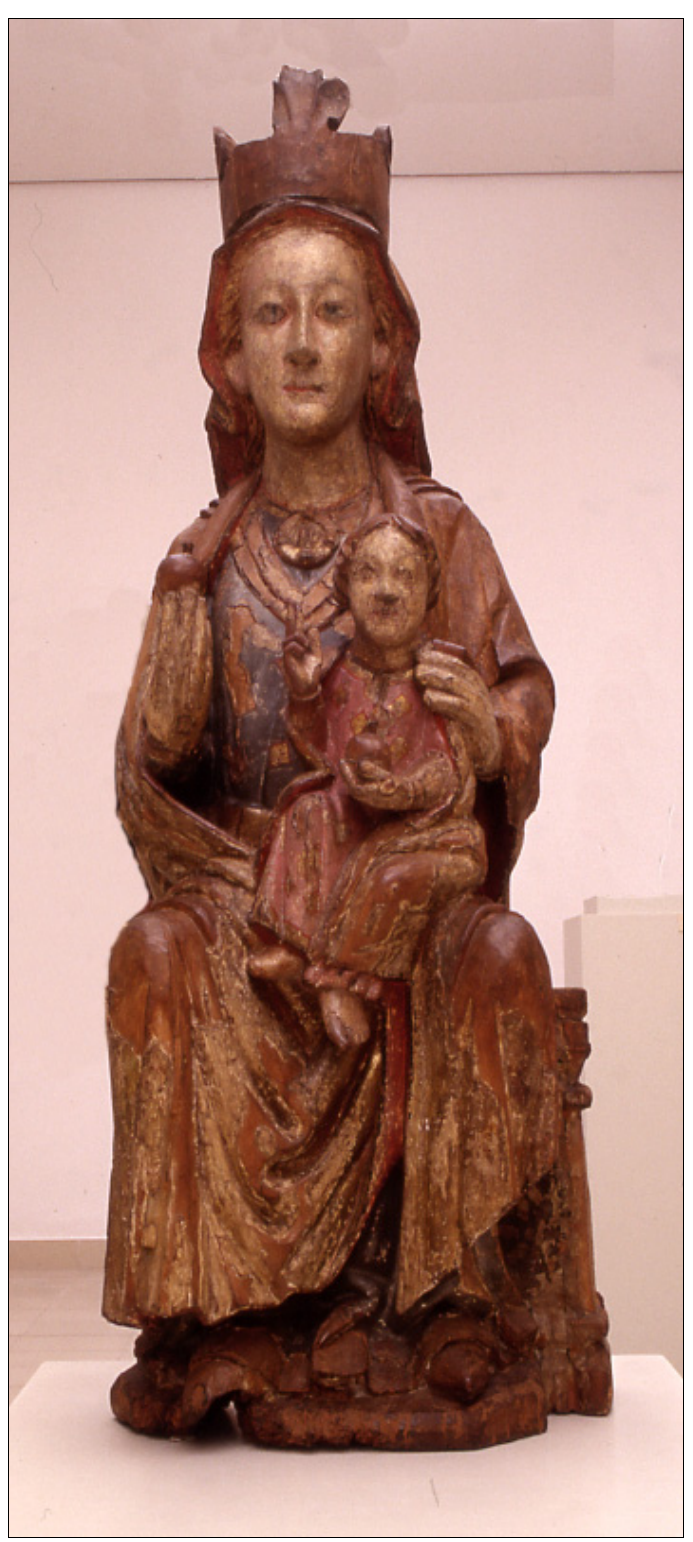

- Lám. 1. Virgen entronizada con el Niño, vista de frente, Colección Gómez Moreno, Granada. Foto Inst. Gómez Moreno. 


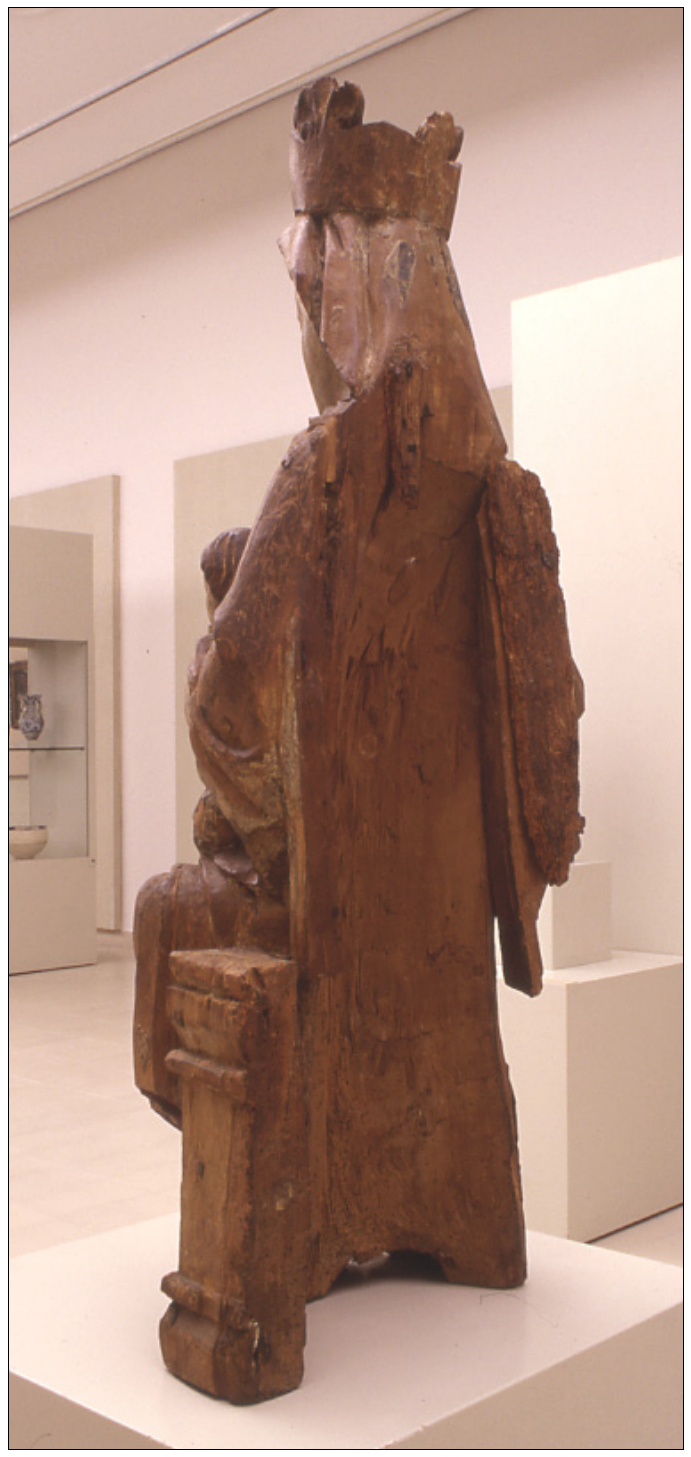

- Lám. 2. Virgen entronizada con el Niño, vista de espalda, Colección Gómez Moreno, Granada. Foto Inst. Gómez Moreno.

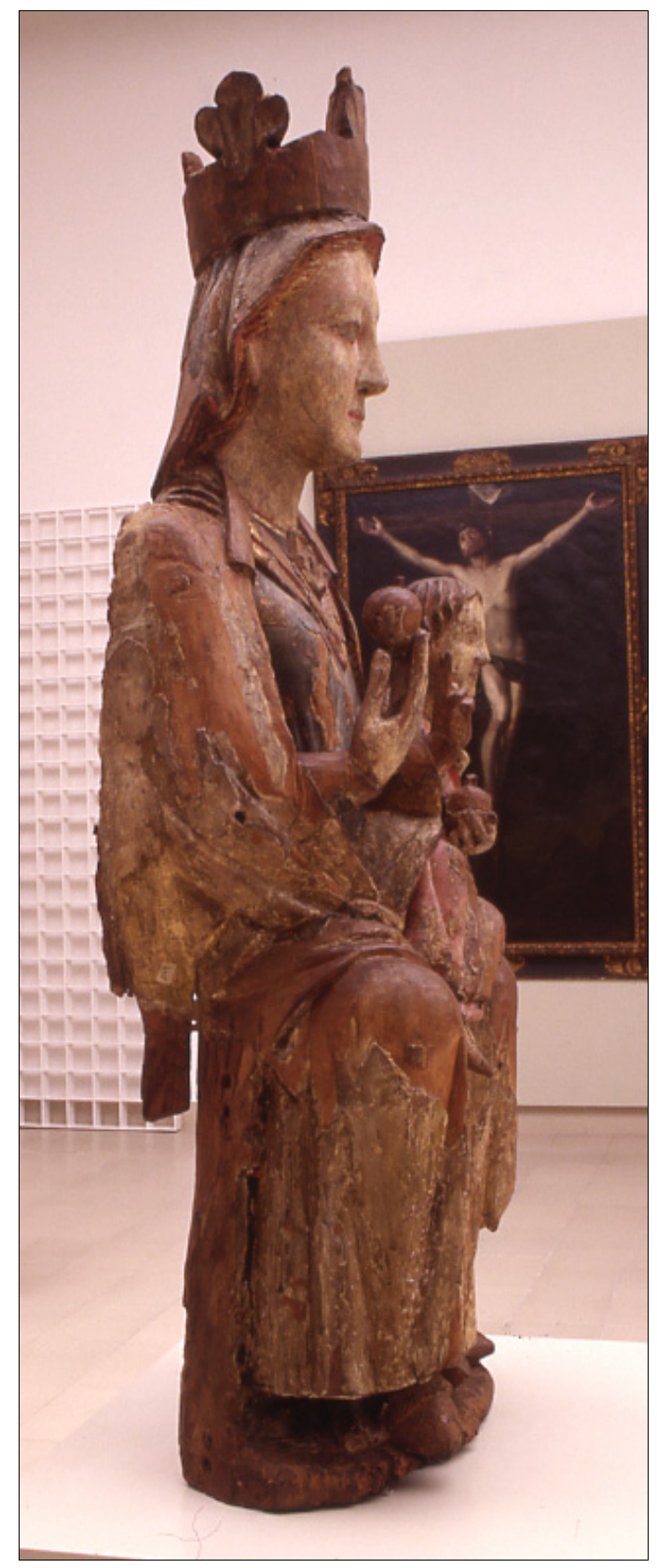

- Lám. 3. Virgen entronizada con el Niño, lado derecho, Colección Gómez Moreno, Granada. Foto Inst. Gómez Moreno. 


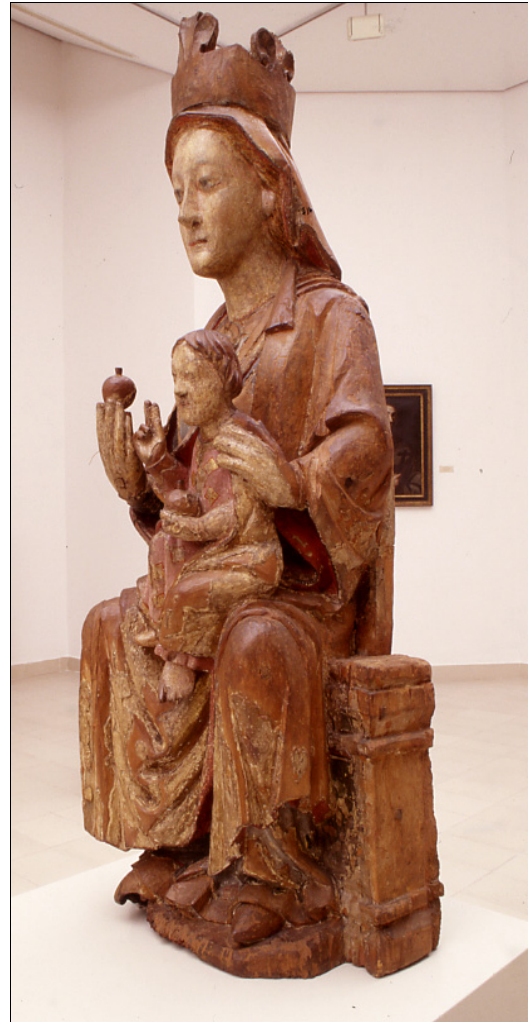

- Lám. 4. Virgen entronizada con el Niño, vista de perfil, Colección Gómez Moreno, Granada. Foto Inst. Gómez Moreno.

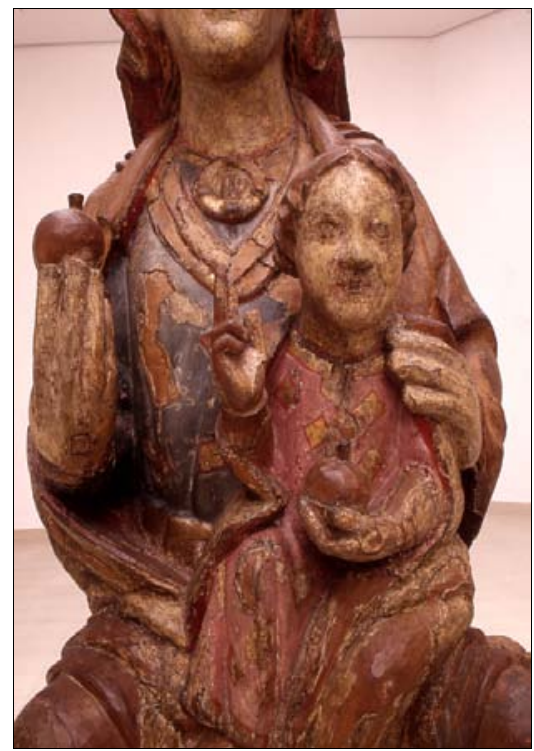

- Lám. 5. Virgen entronizada con el Niño, detalle, Colección Gómez Moreno, Granada. Foto Inst. Gómez Moreno.

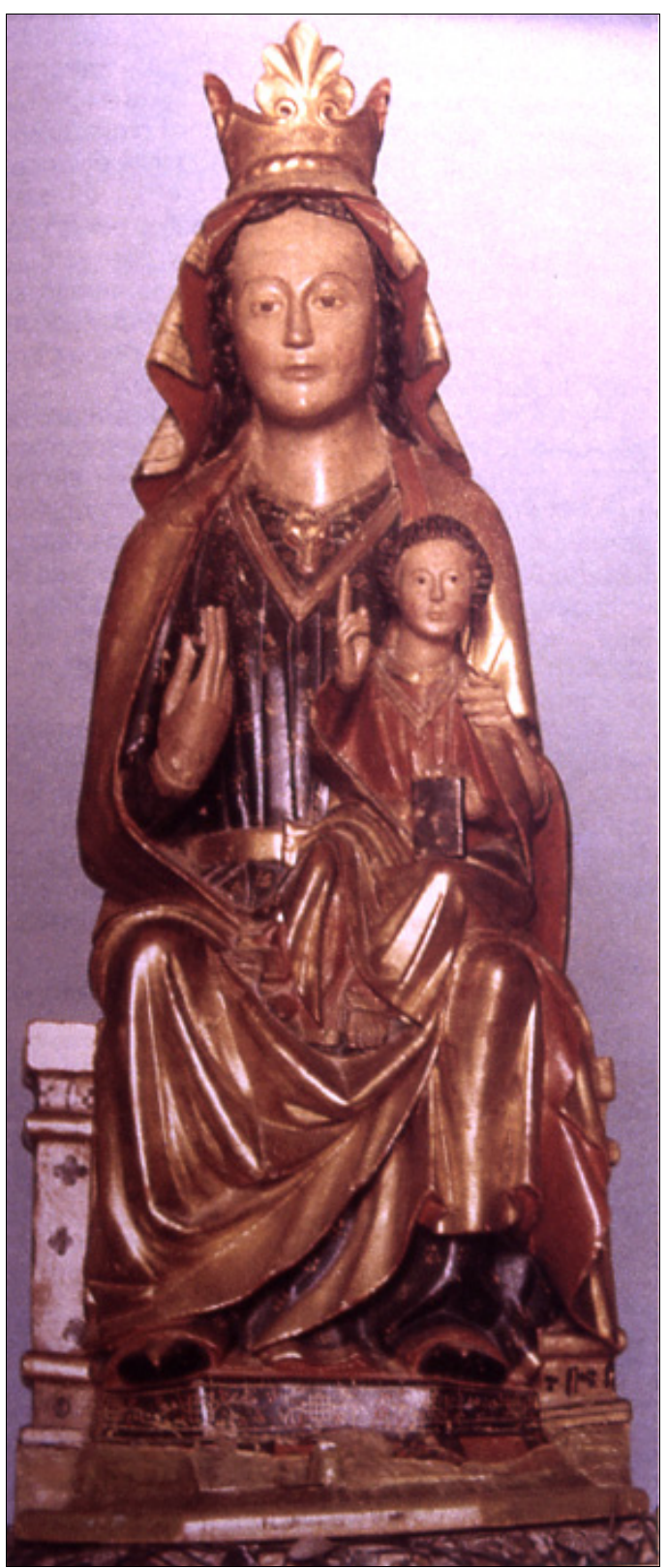

- Lám. 6. Virgen entronizada con el Niño, Parroquia de Fitero (Navarra). Foto C. Fernández Ladreda. 


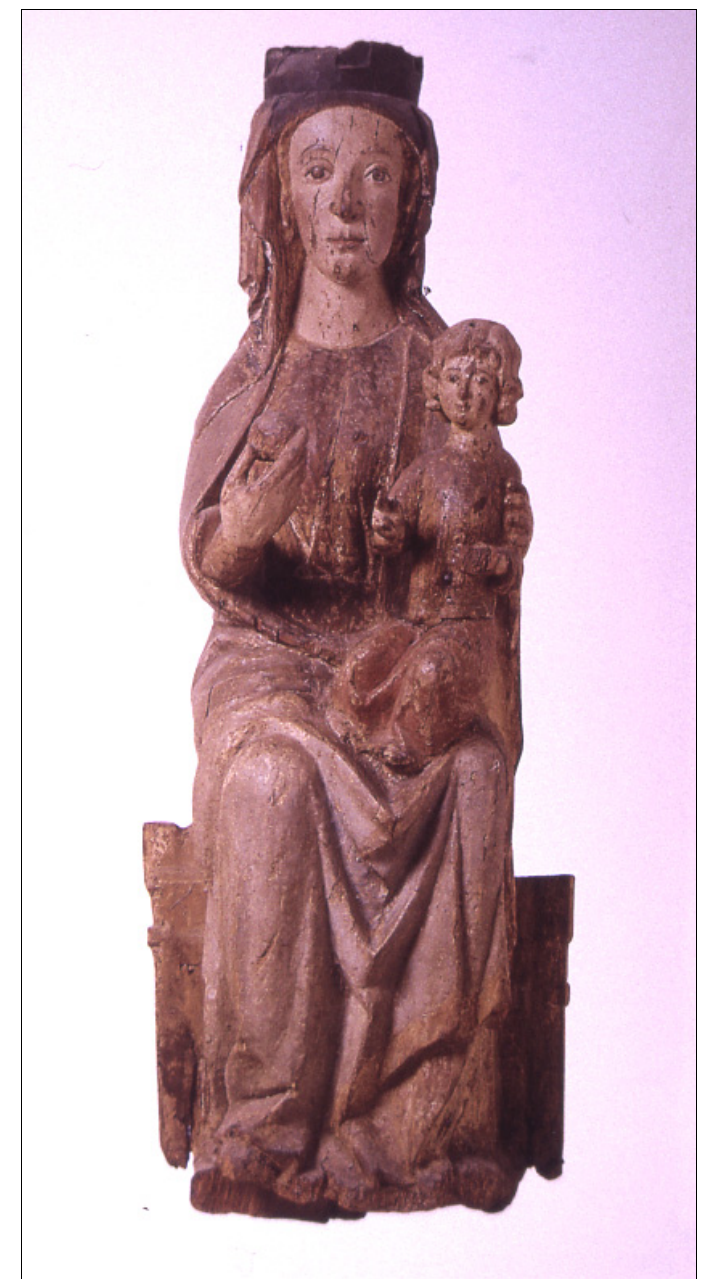

- Lám. 7. Virgen sedente con Niño, procede del monasterio de Sandoval, Museo CatedralicioDiocesano (León). Foto Gómez Rascón.

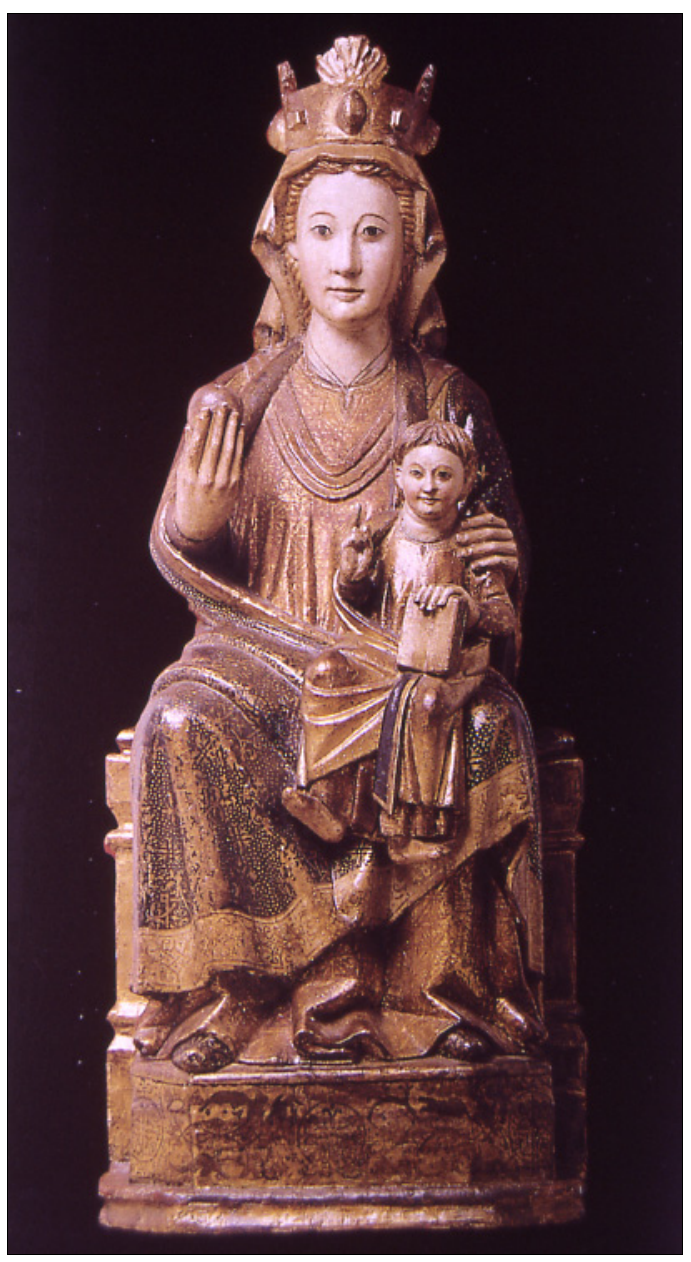

- Lám. 8. Virgen sedente con Niño, monasterio de Santa María la Real, de Gradefes (León). Foto Gómez Rascón. 